\title{
Diagnostic Significance of Serum Ascites Cholesterol to Differentiate Malignant and Non Malignant Ascites
}

\author{
Maneesh Sulya $^{1}$, Ashish Kosthi*1, U.R. Singh ${ }^{2}$ and Reeni Malik ${ }^{1}$ \\ Department of Pathology, Gandhi Medical College, Bhopal, India \\ Department of Pathology, Shyam Shah Medical College, Rewa, India
}

\begin{abstract}
Background: Ascitic fluid usually forms slowly as a result of obstruction of proximal vascular systems (Venous, lymphatic). It may also form directly in response to disease involving the peritoneum. Differentiation between malignancy related and non-malignant ascites is a challenge that is not always met satisfactorily. Both malignant and tuberculous ascites are exudative in nature with lymphocytic predominance and low Serum Ascitic Fluid Albumin Gradient values can not be differentiated easily form each other. Studies have shown that parameters like ascitic fluid cholesterol have been superior to the conventional method of ascitic fluid analysis in discriminating ascites caused by malignancy from others.

Method: This study was conducted in the Department of Pathology, Shyam Shah Medical College, Rewa during the period from May 2009 to October 2011. The study comprised of 100 patients with different causes of ascites admitted to wards of S.G.M.H. Rewa.

Result: Cases were divided in to 3 groups. Groups I consists of patents (39 male and 31 female) with ascites due to chronic liver disease and other non-tubercular and non neoplastic diseases, Group II consists of 20 patients (4 male and 16 female) with ascites due to tuberculosis, Group III consists of 10 patients (4 male and 6 female) with ascites due to malignant diseases. Ascitic fluid cholesterol level was found to be $32.9571 \pm 7.1183 \mathrm{mg} \%, 0.05 \pm 9.047 \mathrm{gm} \%, 74.1 \pm 16.1707 \mathrm{mg} \%$ in Group I, Group II and Group III respectively. On comparing Group III with I and II values were found to be highly significant $(\mathrm{p}<0.005)$ and Group I with II was found to be insignificant $(\mathrm{p}>0.05)$. The value of ascitic fluid cholesterol level found in Group III was comparatively higher ( $>54.5 \mathrm{mg} \%)$ than Group I and Group II with an exception in one case, where we found a higher level of cholesterol.
\end{abstract}

Conclusion: In our study we found a significant raised cholesterol level (74.1 $\pm 16.1707 \mathrm{mg} \%)$ well above the cut off value (54.5mg\%) and it has got a good differentiating potential for determining malignant ascites from non-malignant ascites.

Keywords: Malignant Ascitis, Portal Hypertension, Serum Ascites Cholesterol, Serum Ascitic Fluid Albumin Gradient

\section{Introduction}

Ascitis defined as accumulation of free fluid in the peritoneal cavity . Ascitic fluid usually forms slowly as a result of obstruction of proximal vascular systems (Venous, lymphatic). It may also form directly in response to disease involving the peritoneum. The commonest cause of ascites is liver cirrhosis $(80 \%)$ followed by malignancy $(10 \%)$, tuberculous peritonitis (2\%), congestive cardiac failure, nephrotic syndrome, and others (3\%). ${ }^{[1,2]}$

Various parameters like ascitic fluid physical examination, cell count, total protein concentration, Serum Ascitic Fluid Albumin Gradient [SAAG], cytology, cholesterol, amylase, lactic acid dehydrogenase, adenosine deaminase, and fibronectin levels have been used to differentiate exudative (ascitic fluid total protein $>2.5 \mathrm{gm} \%$ ) and transudative (ascitic fluid total protein $\leq 2.5 \mathrm{gm} \%$ ) ascites of different etiologies. ${ }^{[3,4]}$.

The physiologically based approach to classify ascites by Serum Ascites Albumin Gradient (SAAG) has completely replaced the traditional way of classification as transudate and exudates. ${ }^{[5,6,7]}$ The serum-ascites albumin gradient (SAAG), based on oncotic-hydrostatic balance, is the subtraction of ascitic fluid concentration from the serum albumin concentration. It has been found to categorize ascites much better than total protein concentration. However, albumin gradient does not explain the etiology of ascites, if SAAG is more $>1.1$, the patient is diagnosed to be having portal hypertension. Cirrhosis, cardiac failure, Budd-Chiari syndrome are some examples of high SAAG. Lesser values indicate that portal hypertension is minimal or absent and therefore that and exudative peritoneal lesion is present. A low gradient $(<1.1 \mathrm{gm} \%)$, in conditions where ascites is not related to portal hypertension, but due to peritoneal cause as in peritoneal malignancy, tuberculous peritonitis, metastatic peritoneal deposits. ${ }^{[5,7,8]}$.Differentiation between malignancy related and nonmalignant ascites is a challenge that is not always met satisfactorily. Both malignant and tuberculous ascites are 
exudative in nature with lymphocytic predominance and low SAAG values and can not be differentiated easily form each other. Fluid cytology has low sensitivity for malignancy as the differentiation between reactive atypical mesothelial cells and malignant cells is sometimes difficult. ${ }^{[9,10]}$ Most of the time, diagnosis in not possible without invasive and expensive investigations like CT abdomen, Biopsy and FNAC of peritoneal nodes and diagnostic laparotomy/laparoscopy. So there is a need for more specific and a highly sensitive new marker in presumptive diagnosis of ascites. Studies have shown that parameters like ascitic fluid fibronectin and cholesterol have been superior to the conventional method of ascitic fluid analysis in discriminating ascites caused by malignancy from others.

A study found that fibronectin levels yielded 79\% diagnostic accuracy in differentiating malignant from non malignant ascites. When compared, ascitic cholesterol has a higher sensitivity than fibronectin levels (100\% Vs. 93\%) in diagnosis of malignant ascites, therefore it is preferred test because of its simplicity and cost effectiveness. ${ }^{[1]}$

\section{Materials and Method}

This study was conducted in the Department of Pathology, Shyam Shah Medical College, Rewa during the period from May 2009 to October 2011. The study comprised of 100 patients with different causes of ascites admitted to wards of S.G.M.H. Rewa.

Cases were divided in to 3 groups. Groups I consists of patents ( 39 male and 31 female) with ascites due to chronic liver disease and other non-tubercular and non neoplastic diseases. Chronic liver disease cases included alcoholic cirrhosis, post necrotic cirrhosis and hepatitis progressing to cirrhosis.

Group II consists of 20 patients ( 4 male and 16 female) with ascites due to tuberculosis.

Group III consists of 10 patients (4 male and 6 female) with ascites due to malignant disease.

The diagnosis was done on the basis of clinical diagnosis along with radiological, haematological, biochemical, histopathological examinations and ascitic fluid findings.

Ascitic fluid and blood samples for biochemical and cytological examination were collected simultaneously. Serum and Ascitic fluid Albumin were estimated in autoanalyser by Bromocresol green. Total Protein were estimated in autoanalyser by Biuret methods. The serum cholesterol and Ascitic fluid cholesterol were also estimated.

\section{Result}

In our present study, we had found that serum ascitic albumin gradient is a better parameter reflecting the oncotio pressure gradient between the vascular bed and the interstitial splanchnic or ascitic fluid. The value more than $1.1 \mathrm{gm} \%$ is highly suggestive of higher oncotic pressure gradient even in the high protein ascites. In our study, we found higher value of SAAG $(1.66 \pm 0.3063 \mathrm{gm} \%)$ in the non tubercular and non malignant cases. Thus its high value $(>1.1 . \mathrm{gm} \%)$ is a good parameter to rule out the cause of ascites due to tubercular and malignant diseases and it should be included along with ascites total protein evaluation.

Total protein and SAAG have no differentiating characteristics between tubercular and malignant ascites, both of them show low value of SAAG and higher value of total protein and the differential diagnosis between these two groups is of problem. Tuberculosis is one of the important cause of ascites in our country. Direct smear of ascitic fluid for AFB gives poor results and invasive procedure for biopsy is generally not done.

In the present study total protein concentration in ascitic fluid in Group I was found to be $1.654 \pm 0.6274$, is significantly lower than in Group II $3.71 \pm 0.4426$ and Group III 4.09 \pm 0.7245 . But the difference between the Group II and III was not significant. When we compared Group I and II, we found't' value 16.60 and ' $p$ ' value $<0.0005$ which is highly significant, but when we compared Group II and III we found ' $\mathrm{t}$ ' value 1.2821 and ' $\mathrm{p}$ ' value $>0.05$ which is highly insignificant, thus the total protein value is not useful in differentiating tubercular from malignant ascites.

In this study we found protein concentration in ascitic fluid was more than $2.5 \mathrm{~g} / \mathrm{dL}$ or more in 11 out of 70 patients in Group I and $3 \mathrm{~g} / \mathrm{dL}$ or more than $3 \mathrm{~g} / \mathrm{dL}$ in 4 patients which in accordance with Sampliner RE's study in 1974. In Group III we found less than $2.5 \mathrm{~g} / \mathrm{dL}$ in 1 out of 10 patients.

A total of 100 patients were taken for study, which included 70 from Group I, 20 from Group II (Tubercular Group) and 10 from Group III (Malignant Group).

In tubercular group, the incidence in males was $4(20 \%)$ and that in females was $16(80 \%)$. And in the malignant group, the incidence in males was $4(40 \%)$ and that in females was $6(60 \%)$. Table No. 1 shows total protein values is significantly raised in Group II and Group III in comparison to Group I, but the difference between Group II and Group III was not significant. Table No. 2 shows that SAAG value is significantly high in Group I as compared to Group II and Group III. Comparison between Group II and group III was insignificant. Table No. 3 shows that ascitic cholesterol is significantly raised in Group III as compared to Group I and Group II. Table No. 4 shows that serum $\mathrm{A} / \mathrm{G}$ ratio was low in Group I as compared to Group II and Group III. Serum Cholesterol does not show significant different amongst these groups. 
Table 1a: Showing Mean S. D. and statistical interpretation of total protein in ascitic fluid.

\begin{tabular}{|l|c|c|c|}
\hline & Group I (gm\%) & Group II (gm\%) & Group III (gm\%) \\
\hline Total Protein & 1.6514 & 3.71 & 4.09 \\
\hline S.D. & 0.6274 & 0.4426 & 0.7245 \\
\hline
\end{tabular}

Table 1b: Comparison of values of total protein in ascitic fluid in various groups.

\begin{tabular}{|l|c|c|c|}
\hline & Group I Vs II & Group I Vs III & Group II Vs III \\
\hline$t$ value & 16.60 & 9.8697 & 1.2821 \\
\hline$p$ value & $<0.0005$ & $<0.0005$ & $>0.05$ \\
\hline Significance, protein & H.S., & H.S., & H.S., \\
\hline
\end{tabular}

Table 2a: Showing Mean S. D. and statistical interpretation of SAAG in ascitic fluid.

\begin{tabular}{|l|c|c|c|}
\hline & Group I (gm\%) & Group II (gm\%) & Group III (gm\%) \\
\hline SAAG & 1.66 & 0.655 & 0.53 \\
\hline S.D. & 0.3063 & 0.2312 & 0.2532 \\
\hline
\end{tabular}

Table $2 \mathrm{~b}$ : Comparison of values of SAAG in ascitic fluid in various groups.

\begin{tabular}{|l|c|c|c|}
\hline & Group I Vs II & Group I Vs III & Group II Vs III \\
\hline $\mathrm{t}$ value & 15.9 & 12.8848 & 1.3061 \\
\hline $\mathrm{p}$ value & $<0.0005$ & $<0.0005$ & $>0.10$ \\
\hline Significance & H.S., $\downarrow$ & H.S., $\downarrow$ & Ins. $\downarrow$ \\
\hline
\end{tabular}

Table 3a: Showing Mean S. D. and statistical interpretation of Cholesterol in ascitic fluid.

\begin{tabular}{|l|c|c|c|}
\hline & Group I (gm\%) & Group II (gm\%) & Group III (gm\%) \\
\hline Cholesterol & 32.9571 & 30.05 & 74.1 \\
\hline S.D. & 7.1183 & 9.047 & 16.1707 \\
\hline
\end{tabular}

Table 3b: Comparison of values of cholesterol in ascitic fluid in various groups.

\begin{tabular}{|l|c|c|c|}
\hline & Group I Vs II & Group I Vs III & Group II Vs III \\
\hline$t$ value & 1.3247 & 8.0473 & 7.9652 \\
\hline$p$ value & $>0.05$ & $<0.0005$ & $<0.0005$ \\
\hline Significance & Ins., $\downarrow$ & H.S., & H.S., \\
\hline
\end{tabular}

Table 4: Showing Mean and S. D. values of serum.

\begin{tabular}{|l|c|c|c|c|c|c|}
\hline \multirow{2}{*}{} & \multicolumn{2}{|c|}{ Group I (gm\%) } & \multicolumn{2}{c|}{ Group II (gm\%) } & \multicolumn{2}{c|}{ Group III (gm\%) } \\
\cline { 2 - 7 } & Mean & S.D. & Mean & S.D. & Mean & S.D. \\
\hline Albumin (gm\%) & 2.7386 & 0.2319 & 2.93 & 0.3114 & 2.83 & 0.2213 \\
\hline Globulin (gm\%) & 3.1586 & 0.2851 & 3.085 & 0.2978 & 2.93 & 0.2908 \\
\hline A/G Ratio & 0.8701 & 0.072 & 0.9565 & 0.1345 & 0.976 & 0.1348 \\
\hline Chole. (mg\%) & 168.86 & 20.7394 & 161.0 & 17.7408 & 166.0 & 20.1108 \\
\hline
\end{tabular}

\section{Discussion}

This study was carried out on 100 patients and they were divided into three groups. Group I consists of 70 patients with ascites due to chronic liver disease and other nontubercular and non neoplastic diseases. Chronic liver disease cases included alcoholic cirrhosis, post necrotic cirrhosis and hepatitis progressing to cirrhosis. The diagnosis was done on the basis of clinical diagnosis and ascitic fluid findings. In this group the diagnosis of patient no. 3, was confirmed as hydatid cyst on the basis of radiological and histopathological examination. The diagnosis of patient no. 6 was confirmed as sickle cell anaemia with hypoproteinemia by haematological and biochemical examination. Diagnosis of patient no. 68, was confirmed as CRF by clinical and biochemical examination. Of the total number of cases, 39 were males and 31 were 
females, with maximum number of patients falling in the age group 13-60 years with mean age 45.87 years in case of males and 41.8 years in females.

Group II consists of 20 patients (4 male and 16 female) with ascites due to tuberculosis, the patients were diagnosed on the basis of clinical diagnosis, ascitic fluid findings and the response to anti-tubercular drugs. Most of the patients fall in the age group 13-40 years with an average age of 37 years in case of males and 28.12 years in females.

Group III consists of 10 patients with ascites due to malignant diseases. The primary malignancy was already diagnosed by clinical and histological examination. Of these cases, 4 were males and 6 females. Most of the patients fall in the age group 41-60 years, with an average age of 59 years in case of males and 52-16 years in females. In the present study total protein concentration in ascitic fluid in Group I was found to be $1.654 \pm 0.6274$, is significantly lower than in Group II $3.71 \pm 0.4426$ and Group III $4.09 \pm 0.7245$. But the difference between the Group II and III was not significant. When we compared Group I and II, we found' $t$ ' value 16.60 and ' $p$ ' value $<0.0005$ which is highly significant, but when we compared Group II and III we found ' $t$ ' value 1.2821 and 'p' value $>0.05$ which is highly insignificant, thus the total protein value is not useful in differentiating tubercular from malignant ascites.

In this study we found protein concentration in ascitic fluid was more than $2.5 \mathrm{~g} / \mathrm{dL}$ or more in 11 out of 70 patients in Group I and $3 \mathrm{~g} / \mathrm{dL}$ or more than $3 \mathrm{~g} / \mathrm{dL}$ in 4 patients which in accordance with Sampliner RE's ${ }^{[6]}$ study in 1974. In Group III we found less than $2.5 \mathrm{~g} / \mathrm{dL}$ in 1 out of 10 patients.

In the present study, SAAG was found in Group I (1.66 \pm 0.3063$)$, it was significantly higher than those found in Group II $(0.655 \pm 0.2312)$ and Group III $(1.53 \pm 0.2532)$. And we compared Group I with II, we found ' $t$ ' value 15.9 and 'p' value $<0.0005$ which is highly significant, on comparing Good I with III, we found ' $\mathrm{t}$ ' value 12.8848 and 'p' value $<0.0005$ which is highly significant, but when we compared Group II with III, we found ' $t$ ' value 1.3061 and 'p' value $>0.05$ which is insignificant, thus value is not useful in differentiating tubercular from malignant ascites.

SAAG value as found in our study are in accordance with the studies of Pare P., Talbot J, Hoefs JC (1983) ${ }^{[5]}$, Runyon BA et al (1988) ${ }^{[14]}$, Goyal AK et al (1989) ${ }^{[15]}$, Alba D. et al (1995) ${ }^{[16]}$.

Another Study: have evaluated the diagnostic value of ascitic fluid cholesterol in differentiating between tuberculous and malignant ascites. They look $54.4 \mathrm{mg} / \mathrm{dl}$ as the cut off value for ascitic cholesterol. The sensitivity, specificity, positive and negative predictive value and overall diagnostic accuracy in differentiating malignant from tuberculous ascites being $89.65 \%, 100 \%, 83.3 \%$ and $93.18 \%$ respectively. ${ }^{[12]}$

Again a study by Vyakaranam et al shows cholesterol has been found to clearly differentiate between tuberculous and malignant ascites. ${ }^{[13]}$ The elevated cholesterol levels in malignancy is due to the increased vascular permeability, increased cholesterol synthesis and release from malignant cells implanted on peritoneum. ${ }^{[10,12]}$ As studies on this are very less, hence the present study has been undertaken to evaluate sensitivity and diagnostic accuracy of ascitic fluid cholesterol level in diagnosing malignant ascites.

In our study, ascitic cholesterol level was found to be $32.957 \pm 7.1183$ in Group I and 30.05 \pm 9.047 and $74.1 \pm 16.1707$ in Group II and Group III respectively. When we compared Group I and II, we found ' $t$ ' value 1.3247 , 'p' value $>0.05$ which shows highly insignificance, on comparing Group I and III, we found ' $t$ ' value 8.0473, 'p' value $<0.0005$ which is highly significant, and again on comparing Group II and III, we found ' $t$ ' value 7.9652, 'p' value $<0.0005$ which is highly significant. Thus, ascitic cholesterol level was found significantly raised in malignant group as compared to Group I and Group II. Our results are in concordance with the studies of Sood A, Garg $\mathrm{R}$ et al (1995) ${ }^{[12]}$.

Our results were in accordance, in chronic liver disease and malignant diseases, with that of Prieto M. et al (1988) ${ }^{[17]}$, Barbare JC, Diab G. et al (1989) ${ }^{[18]}$ and Castaldo G., Oriani G. et al (1994) ${ }^{[19]}$.

\section{Conclusion}

Total protein and SAAG have no differentiating characteristics between tubercular and malignant ascites, both of them show low value of SAAG and higher value of total protein and the differential diagnosis between these two groups is of problem. In our study we found a significant raised cholesterol level $(74.1 \pm 16.1707 \mathrm{mg} \%)$ well above the cut off value $(54.5 \mathrm{mg} \%)$ and it has got a good differentiating potential for determining malignant ascites from non-malignant ascites.

The lower value of cholesterol is a good indicator to rule out malignancy. This technique being simple, cost effective and easily available, it should be included alongwith other examinations (SAAG, ascitic fluid total and differential WBC count, and cytology), at least in cases of ascites with suspected malignancy.

\section{Acknowledgment:}

Dr U.R. Singh, HOD Department of Pathology, SSMC, Rewa; Dr. Reeni Malik, HOD Department of Pathology, 
GMC, Bhopal. and Dr. Ashish Koshti, Associate Professor, Department of Pathology, GMC, Bhopal, India.

\section{Ethical Approval}

The study was approved by the Institutional Ethics Committee.

\section{References}

1. Runyon BA. Management of adult patients with ascites due to cirrhosis. AASLD Practice Guideline. Hepatology 2004;39: 1-16.

2. Moore KP, Aithal GP. Guidelines on the management of ascites in cirrhosis. Gut 2006;55 Suppl 6: vi1-12.

3. Paddock F. The diagnostic signficance of serous fluids in Disease. New England Journal of Medicine 1940; 223: 1010.

4. Gerbes AL, Jüngst D, Xie YN, Permanetter W, Paumgartner G. Ascitic fluid analysis for the differentiation of malignancyrelated and nonmalignant ascites. Proposal of a diagnostic sequence. Cancer 1991;68: 1808-1814.

5. Paré P, Talbot J, Hoefs JC. Serum-ascites albumin concentration gradient: a physiologic approach to the differential diagnosis of ascites. Gastroenterology 1983;85: 240-244.

6. Sampliner RE, Iber FL. High protein ascites in patients with uncomplicated hepatic cirrhosis. Am J Med Sci 1974;267: 275-279.

7. Rector WG Jr, Reynolds TB. Superiority of the serum-ascites albumin difference over the ascites total protein concentration in separation of "transudative" and "exudative" ascites. Am J Med 1984;77: 83-85.

8. Rector WG Jr. An improved diagnostic approach to ascites. Arch Intern Med 1987;147: 215.

9. Jain SC, Misra SM, Misra NP, Tandon PL. Diagnostic value of ascitic fluid xamination. J Asso Physic India. 1996;14:59-69.
10. Rana SV, Babu SG, Kocchar R. Usefulness of ascetic fluid cholesterol as a marker for malignant ascites. Med SciMon. 2005;11:136-42.

11. Colli A, Cocciolo M: Ascitic fluid analysis in hepatocellular carcinoma cancer 1993, 72 (3), 677-82.

12. Sood A., Garg R., Kumar R., et al.: Ascitic fluid cholesterol in malignant and tubercular ascites; JAPI, 1995,43, 745-47.

13. Vyakaranam S, Nori S, Sastry GM, Vyakaranam SB, Bhongir AV. Serum - Ascites Albumin and Cholesterol Gradients in Differential Diagnosis of Ascites. NJIRM. 2011;2(3):22-8.

14. Runyon B.A., Montano A.A.: The serum ascites albumin gradient is superior to the exudates-transudate concept in the differential diagnosis of ascites; Ann. Intern. Med. 1992,117(3), 215-20.

15. GoyalA.K., GoyalS.K. et al: Differentail diagnosis of Ascitic fluid, evaluation and comparison of various biochemical criteria with a special reference to serum ascites albumin concentration gradient and its relation to portal pressure; Trop. Gastroenterol 1989,10(1), 515.

16. Alba D., Torres E, V Azquez JJ. Sero-ascitic gradient of albumin, usefulness and diagnostic limitations; An. Med. Interna 1995, 12 (8), 404-7.

17. Prieto M., Gomez-Lechon M.J. et al: Diagnosis of malignant ascites, comparison of ascitic fibronectin, cholesterol, and serum ascites albumin difference; Dig Dis Sci 1988, 33 (7), 833-38.

18. Barbare J.C., Diab G.et al: Concentration of lipids in ascitic fluid and the concentration gradient of albumin in blood and ascites; Diagnostic Significance Ann. Gastroenterol Hepatol (Paris) 1989,25 (6), 251-6.

19. Castaldo G., Oriani G. et al: Total discrimination of peritoneal malignant ascites from cirrhosis and hepatocarcinoma associated ascites by assays of ascitic cholesterol and lactate dehydrogenase; Clin. Chem. 1994, 40 (3), 478-83.

*Corresponding author:

Dr. Ashish Kosthi, Department of Pathology, Gandhi Medical College, Bhopal, India

Phone: +91 9826609403

Email: drashishpath@gmail.com

Financial or other Competing Interests: None.

Date of Submission : 23.02.2017

Date of Acceptance : 08.07.2017

Date of Publication : 25.10.2017 